\title{
ВИЗНАЧЕННЯ ЯКІСНОГО СКЛАДУ СУЧАСНИХ РАНОЗАГОЮВАЛЬНИХ ЛІКАРСЬКИХ ЗАСОБІВ ДЛЯ ПОТРЕБ МЕДИЧНОЇ СЛУЖБИ ЗБРОЙНИХ СИЛ УКРАЇНИ У МИРНИЙ ЧАС ТА НА ОСОБЛИВИЙ ПЕРІОД
}

\author{
А.М. Соломенний
}

Українська військово-медична академія, м. Київ, Україна

Вступ. Ранозагоювальні препарати, які знаходяться на оснащенні підрозділів військово-медичної служби мають ряд недоліків, серед яких основними є недостатня регенеративна активність, високий ризик мікробної контамінації рани та необхідність частої заміни на рановому полі. Тому надзвичайно актуальними стають дослідження, спрямовані на розробку технологічних схем отримання сучасних м'яких лікарських засобів комплексної дії вітчизняного виробництва для місцевого лікування ран, а також введення до норм постачання таких ранозагоювальних лікарських засобів, як мазі та ранові гідрогелеві пов'язки, які мають антибактеріальні, анестезуючі, протизапальні та антимікробні властивості, а також не вимагають частої заміни у процесі медикаментозного забезпечення військовослужбовців.

Мета дослідження - дослідити якісний склад сучасних ранозагоювальних лікарських засобів для потреб медичної служби Збройних сил Украӥни у мирний час та на особливий період.

Матеріали та методи. Матеріалами слугували медичні картки стаціонарних хворих та листи призначень поранених та хворих із пошкодженням шкірних покривів. у роботі застосовано документальний, загальногістологічний, гістохімічний, морфометричний та статистичний методи дослідження.

Результати дослідження. 3 метою визначення якісного складу норм постачання ранозагоювальних засобів місцевої дії нами були проаналізовані медичні картки стаціонарних хворих та листи призначень поранених та хворих із пошкодженням шкірних покривів. У модель дослідження були включені умовно забруднені рани діаметром 10 см та глибиною рани від 5 до 10 мм. Здійснено аналіз результатів медикаментозного забезпечення хворих із гнійно-запальними процесами м'яких тканин, які знаходилися на лікуванні з приводу гнійних ран та інтраопераційної профілактики ранової інфекції в 65 хворих, що склали основну групу. Аналіз ефективності застосування розробленої МдМ-мазі при лікуванні гнійних ран проводився в порівнянні з результатами лікування 110 пацієнтів з гострими гнійними первинними ранами (72,5 \%), що склали групу порівняння, яка була розділена на 5 підгруп. Серед них абсцеси м'яких тканин, флегмони клітинних просторів тулуба і кінцівок спостерігалися в 54 (35,2 \%) хворих, різні форми панарицію - 25 (16,2 \%) і парапроктиту - 12 (8,9\%) пацієнтів. Порівно розподілилися хворі з гострим гнійнім бурситом, карбункулом (12,1% спостережень). Результати мікробіологічних досліджень ранових виділень були позитивними у всіх груп пацієнтів. При цьому в 60 хворих (44,7\%) флора представлена монокультурою, в інших пацієнтів з рани виділені асоціації мікроорганізмів. У мікробному пейзажі спостерігалася перевага грампозитивної флори. Більшість ідентифікованих мікроорганізмів склали стафілококи, серед яких найчастіше виділявся S. aurerus (55,6 \% пацієнтів), при чіткій тенденції до підвищення ролі S. еріdermidis (30,8 \% хворих), а також S. faecalis (15,5\% хворих). У ряді грамнегативних бактерій переважали E. coli (76,4 \% хворих), значно рідше спостерігалися бактерії роду Proteus $(11,7 \%$ хворих), Pseudomonas aerugenosa (3,7 \% хворих) і клебсієла - 1,9\%. Ентерококи виділені - у 5,6\%, B. subtilis у 2,8 \% хворих. Серед хворих, що спостерігались, у 8 чоловік були виділені такі мікроорганізми: палички групи Bacteroides - 5 пацієнтів, з них у 2 бактероїди групи B. fragilis, а в трьох - B. melaninogenicus. У двох чоловік виявлені грампозитивні коки групи Peptostreptococcus sp., і в одного пацієнта була виділена факультативно анаеробна мікрофлора. При аналізі перебігу ранового процесу в ході лікування хворих розробленою маззю під умовною назвою «МДМ-мазь» звертає на себе увагу швидке зменшення запально-ексудативних змін у рані, в основному до 3 доби лікування. Оцінюючи ефективність антимікробної дії розробленої мазі необхідно підкреслити, що вона пригнічує внутрішньотканинну мікрофлору, що не досягається при лікуванні іншими мазями, що обумовлено як гідрофільною основою, так і активними фармацевтичними інгредієнтами, тому що саме внутрішньотканинна мікрофлора визначає тяжкість і спрямованість ранового процесу.

Висновки. Отримані результати свідчать про високу ефективність розробленої ранозагоювальної мазі з метилурацилом, декаметоксином та ментолом під умовною назвою «МдМ-мазь» з протизапальною, антимікробною та анестезуючою дією для використання в гнійно-запальну фазу ранового процесу. Основними факторами при цьому є: активний вплив на перебіг запального процесу в рані, а також істотне зниження виразності ендогенної інтоксикації при гнійно-запальних процесах м'яких тканин. На даному етапі розвитку медичної науки і практики визначені оптимальні схеми застосування ранозагоювальних засобів у обраних клініко-економічних групах для місцевого лікування ран.

Ключові слова: мазь, рановий процес, запалення, поранення. 
Вступ. Однією з найбільших проблем, що постає перед військовими лікарями в мирний час, а також постала при веденні бойових дій в умовах проведення операції Об'єднаних сил та антитерористичної операції (ООС (АТО)) та, ймовірно, буде потребувати вирішення на етапі наступного лікування i реабілітації поранених військовослужбовців, $є$ оптимізація схем місцевого лікування ран та профілактики ранової інфекції, яке повинно здійснюватися у суворій відповідності 3 фазами ранового процесу $[1,4,19,20]$.

Слід зазначити, що медичне постачання $\epsilon$ невід'ємною складовою частиною медичного забезпечення, призначеною для своєчасного i безперебійного постачання військ медичною технікою і майном з метою всебічного виконання комплексу лікувальнопрофілактичних, санітарно-гігієнічних та протиепідемічних заходів [12].

Ранозагоювальні препарати, які знаходяться на оснащенні підрозділів військово-медичної служби мають ряд недоліків, серед яких основними $\epsilon$ недостатня регенеративна активність, високий ризик мікробної контамінації рани та необхідність частої заміни на рановому полі $[13,17]$.

Тому надзвичайно актуальними стають дослідження, спрямовані на розробку технологічних схем отримання сучасних м'яких лікарських засобів (МЛЗ) комплексної дії вітчизняного виробництва для місцевого лікування ран, а також введення до норм постачання таких ранозагоювальних лікарських засобів, як мазі та ранові гідрогелеві пов'язки, які мають антибактеріальні, анестезуючі, протизапальні та антимікробні властивості, а також не вимагають частої заміни у процесі медикаментозного забезпечення військовослужбовців [5-8].

Мета дослідження - дослідити якісний склад сучасних ранозагоювальних лікарських засобів для потреб медичної служби Збройних сил України у мирний час та на особливий період.

Матеріали та методи дослідження. Метою нашого дослідження було визначення якісного складу норм постачання сучасних ранозагоювальних м'яких лікарських засобів для потреб медичної служби Збройних сил України у мирний час та на особливий період. В цьому аспекті необхідним $є$ оцінка та аналіз даних, які характеризують структуру поранень та пошкоджень військовослужбовців під час ведення бойових дій або виникнення надзвичайних станів, а також визначення основних фармакотерапевтичних груп лікарських засобів (ЛЗ) для місцевого лікування ран. Наступний етап передбачає визначення відповідних схем застосування ранозагоювальних засобів шляхом аналізу медичних карток стаціонарних хворих та листків лікарських призначень поранених та хворих із пошкодженнями шкірних покривів $[9,16]$.

Морфологія ранового процесу вивчена 3 використанням цитологічних і гістологічних досліджень. Порівняльне морфологічне вивчення проведене з використанням сучасних загальногістологічних, гістохімічних i морфометричних методик дослідження $[3,10$, $14,18,20]$.

Предметом вивчення послужили шматочки тканини гнійних ран у процесі репарації у хворих, яких лікували розробленою маззю $з$ метилурацилом, декаметоксином та ментолом під умовною назвою «МДМ-мазь» (основна група) і в хворих під впливом мазей інших фірм-виробників (група порівняння) у терміни від першої до п'ятнадцятої доби.

Визначення площі рани 3 наступним обчисленням швидкості загоєння рани проводили за методикою А. В. Стефанова [18].

Швидкість загоєння ран розраховували за формулою (1):

$$
V=\frac{S_{y}-S_{t}}{S_{y}} 100
$$

де $\quad V$ - швидкість загоєння рани, \%;

$S_{y}$ - початкова площа рани, мм;

$S_{t}$ - площа рани в день вимірювання, мм.

Статистична обробка отриманих даних здійснювалася за методикою, що наведена в Державній фармакопеї України $[11,20]$.

Результати дослідження та їх обговорення. Після нанесення рани внаслідок різноманітних факторів застосування сучасної зброї, у тому числі при пораненнях вогнепальною зброєю спрямованість боротьби з рановою інфекцією ускладнюється тим, що часто рани інфіковані патогенними антибіотико-резистентними штамами стафілококів, умовно патогенною мікрофлорою, а також мікробними асоціаціями. У виникненні гнійних ускладнень зросла роль антибіотикорезистентної внутрішньогоспітальної інфекції [2].

Процес формування резистентних мікроорганізмів у рівній мірі поширюється не 
тільки на групу антибіотиків, але і на традиційні антисептики, що істотно ускладнює лікування ран та вимагає створення препаратів із широким спектром антибактеріальної дії, а також із протизапальним та знеболюючим ефектами та включення їх до норм постачання медичного майна для потреб військовомедичної служби $[12,15,19]$.

3 метою визначення якісного складу норм постачання ранозагоювальних засобів місцевої дії нами були проаналізовані медичні картки стаціонарних хворих та листи призначень поранених та хворих із пошкодженням шкірних покривів.

У модель дослідження були включені умовно забруднені рани діаметром 10 см та глибиною рани від 5 до 10 мм.

Рани характеризувались наявністю серозно-геморагічного пошкодженням сполучно-епітеліальної тканини, колікваційним некрозом, дегенеративно-запальним типом ранових відбитків, перифокальним запаленням країв рани, а також спостерігалася незначна адаптація стінок і країв рани.

Проведений аналіз результатів медикаментозного забезпечення хворих із гнійно-запальними процесами м'яких тканин, які знаходилися на лікуванні 3 приводу гнійних ран та інтраопераційної профілактики ранової інфекції в 65 хворих, що склали основну групу. Аналіз ефективності застосування розробленої МДМ-мазі при лікуванні гнійних ран проводився в порівнянні 3 результатами лікування 110 пацієнтів 3 гострими гнійними первинними ранами $(72,5 \%)$, що склали групу порівняння, яка була розділена на 5 підгруп. Серед них абсцеси м'яких тканин, флегмони клітинних просторів тулуба і кінцівок спостерігалися в 54 (35,2 \%) хворих, різні форми панарицію - 25 $(16,2 \%)$ і парапроктиту - 12 (8,9 \%) пацієнтів. Порівно розподілилися хворі 3 гострим гнійнім бурситом, карбункулом $(12,1 \%$ спостережень).

У всіх хворих, які спостерігались, досліджувалися загальний аналіз крові; при підрахунку гемограми обчислювався лейкоцитарний індекс інтоксикації (ЛII), а також індекс зсуву нейтрофілів. Про наявність і виразність синдрому ендогенної інтоксикації судили за рівнем «середніх молекул» (СМ) у сироватці крові.

У хворих, які спостерігались, після видалення гнійного вогнища зберігалося помірне перифокальне запалення країв рани, а також спостерігалася незначна адаптація стінок і країв рани.

Результати

досліджень ранових виробілогіних позитивними у всіх груп пацієнтів. При цьому в 60 хворих (44,7 \%) флора представлена монокультурою, в інших пацієнтів 3 рани виділені асоціації мікроорганізмів. $\mathrm{y}$ мікробному пейзажі спостерігалася перевага грампозитивної флори. Більшість ідентифікованих мікроорганізмів склали стафілококи, серед яких найчастіше виділявся S. aurerus (55,6 \% пацієнтів), при чіткій тенденції до підвищення ролі $S$. epidermidis (30,8 \% хворих), а також $S$. faecalis $(15,5 \%$ хворих). У ряді грамнегативних бактерій переважали E. coli $(76,4$ \% хворих), значно рідше спостерігалися бактерії роду Proteus (11,7 \% хворих), Pseudomonas aerugenosa $(3,7 \%$ хворих) і клебсієла - 1,9 \%. Ентерококи виділені - у 5,6 \%, B. subtilis - у 2,8 \% хворих. Серед хворих, що спостерігались, у 8 чоловік були виділені такі мікроорганізми: палички групи Bacteroides - 5 пацієнтів, 3 них у 2 бактероїди групи $B$. fragilis, а в трьох B. melaninogenicus. У двох чоловік виявлені грампозитивні коки групи Peptostreptococcus $s p .$, і в одного пацієнта була виділена факультативно анаеробна мікрофлора.

При розкритті гнійного вогнища мікробна обсіменіння рани було значно вищим критичного рівня і дорівнювала в середньому 1010-1012 КУО. Величина $\mathrm{pH}$ ранового ексудату безпосередньо після розкриття гнійника склала $3,6 \pm 1,6$.

При цитологічному дослідженні рановий процес характеризувався дегенеративним типом клітинної реакції. У мазках відзначалася виражена бактеріальна обсіменіння рани. Фагоцитоз носив незавершений характер.

При аналізі перебігу ранового процесу в ході лікування хворих розробленою маззю під умовною назвою «МДМ-мазь» звертає на себе увагу швидке зменшення запальноексудативних змін у рані, в основному до 3 доби лікування. Останні знайшли своє підтвердження в клінічній картині (значно зменшилися прояви загальної інтоксикації організму, зникали тахікардія, болі в рані, слабість, нормалізувалася температура тіла), даних лабораторних досліджень (нормалізувалося число лейкоцитів у периферичній крові, швидкість осідання еритроцитів, знизилися рівень ЛІІ і рівень СМ у сироватці крові). У цей період лікування 
активізувалися процеси очищення ран від нальоту фібрину, крапкових ділянок некрозу, зменшувалася кількість виділень, рановий ексудат мав серозний вид, поліпшувалося кровопостачання навколоранової зони. Тривалість фази запалення в хворих, у лікуванні яких використовували «МДМ-мазь», скоротилася майже вдвічі, у порівнянні 3 хворими групи порівняння.

У хворих основної групи вже на другутретю добу лікування з рани не висівалися патогенні стафілококи, далі - протей i кишкова паличка. Відзначалась також висока ефективність розробленої мазі при лікуванні гнійних ран, інфікованих паличкою синьозеленого гною, елімінація якої 3 ран відзначалась на 4-5 добу лікування. На 7-у добу 82,3 \% посівів не давали росту мікрофлори, мікроорганізми виявлялися лише в 12,8 \% пацієнтів, причому частіше непатогенні або умовно-патогенні.

На противагу цьому в ранах хворих групи порівняння на 3-ю і 5-у добу досліджень позитивної динаміки лікування за даними мікробіологічного контролю відзначено не було: у 65 \% пацієнтів висівалася мікрофлора різного характеру, переважно як у монокультурі, так і в асоціації 3 іншими мікроорганізмами. Особливого значення набувають госпітальні штами - грамнегативні мікроорганізми - Acinetobacter spp. При бактеріологічному дослідженні на 7-у добу в 59,8 \% посівів був отриманий ріст мікрофлори. При цьому основним збудником у рані залишався патогенний плазмокоагулюючий S. aures як у монокультурі, так і в асоціації 3 іншими мікроорганізмами. У той час у порівнянні 3 вихідними показниками збільшилося число грамнегативної мікрофлори. При бактеріологічному обстеженні на 10-у добу в 19,7 \% посівів отриманий ріст такої мікрофлори, у більшості випадків це були P. aeruginosa, Proteus vulgaris et mirabilis, E.coli. Зареєстровано приєднання до наявної в рані мікрофлори внутрішньогоспітальних штамів, частіше грамнегативних.

Оцінюючи ефективність антимікробної дії розробленої мазі необхідно підкреслити, що вона пригнічує внутрішньотканинну мікрофлору, що не досягається при лікуванні іншими мазями, що обумовлено як гідрофільною основою, так і активними фармацевтичними інгредієнтами, тому що саме внутрішньотканинна мікрофлора визначає тяжкість і спрямованість ранового процесу.

Результати кількісного визначення мікрофлори рани до лікування свідчили, що у всіх випадках у тканинах рани число мікробних тіл на 1 г складало $10^{10-10^{12}}$, тобто було вище критичного рівня. У процесі місцевого лікування маззю «МДМ-мазь» кількість мікрофлори, що висівається з рани, прогресивно знижувалася до 3-5-ї доби і у всіх випадках була нижче критичного рівня (p < 0,05), що дозволяє порушувати питання про раннє оперативне закриття рани. Навпроти, у хворих групи порівняння на 3-ю і 5-у добу досліджень позитивна динаміка лікування за даними мікробіологічного контролю незначна: рівень бактеріального обсіменіння ран у 65\% випадків вище критичного. На 7-у добу лікування зберігалося високе бактеріальне обсіменіння ран у 59,7 \% випадків кількість мікробів на 1 г тканини було вище критичної.

У комплексі лікувальної дії розроблена «МДМ-мазь» проявляє також і стимулюючий ефект на процеси регенерації в рані. При цьому репаративні процеси, різко пригнічені гнійною інфекцією, активізувалися вже на ранніх етапах перебігу патологічного процесу.

У хворих групи порівняння, незважаючи на зниження мікробної забрудненості ран нижче критичного рівня (< $10^{5}$ мікробних клітин на 1 г тканини), до 7 доби лікування відзначене мляве очищення рани, місцями наліт фібрину на слабко розвинутій грануляційній тканині, причому 6 хворим (3,8 \%) потрібна була повторна хірургічна обробка. Переважним типом цитограм навіть на 7-у добу був запальний (61,4 \%), рідше запально-регенеративний $(15,8 \%)$ і ще рідше регенеративно-запальний $(13,5 \%)$ i регенераторний $(9,3 \%)$ типи ранових відбитків. Таким чином, лише в 23,1 \% хворих групи порівняння на 5-у добу лікування були створені умови для проведення відновних операцій.

Проведене морфологічне дослідження переконливо показало, що загоєння гнійних ран у хворих групи порівняння характеризується пролонгованими запальними змінами, які розвиваються на тлі розладів системи мікроциркуляції, що значно гальмує процеси репарації, при цьому тривалий час у знову утвореній грануляційній тканині зберігаються мікроабсцеси й ознаки вторинного некротизування. Застосування розробленої мазі «МДМ-мазь» вже в першу 
добу, з одного боку, самостійно розчиняє лейкоцитарно-некротичний шар, 3 іншого боку, активний фармацевтичний інгредієнт метилурацил приймає участь у численних цитологічних процесах клітин, сприяє активації мікро- і макрофагоцитозу в гнійносептичній рані в 3,6 рази. При цьому практично не визначаються мікроабсцеси i вторинні некрози новоствореної тканини, спостерігається більш раннє формування грануляційної тканини, активізування процесів фібріногенезу та епітелізації ранової поверхні.
Показник швидкості загоєння рани $\epsilon$ відносним і дає можливість характеризувати динаміку перебігу ранового процесу незалежно від різниці величини площ ран. Розрахунки проводили згідно формули, яка наведена в матеріалах та методах.

Спостереження за процесом загоєння ран показали, що починаючи 3 3-го дня експерименту площа ран у всіх груп скорочувалась.

Результати досліджень динаміки скорочення площі поверхні рани представлені в таблиці.

Таблиця

Планіметричні показники швидкості загоєння ран та скорочення площі ранової поверхні

\begin{tabular}{|c|c|c|c|c|c|c|c|c|}
\hline 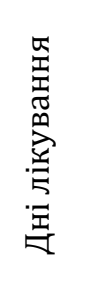 & 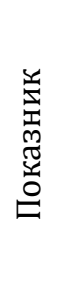 & 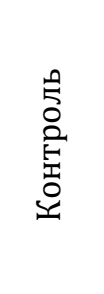 & 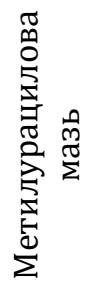 & 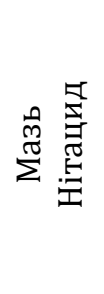 & 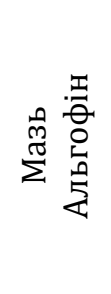 & 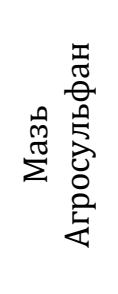 & 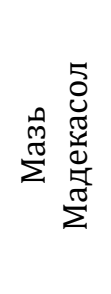 & 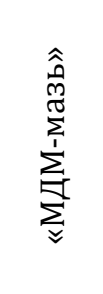 \\
\hline 1-й & $\mathrm{S}_{\mathrm{y}}$ & 101 & 100 & 102 & 100 & 100 & 101 & 100 \\
\hline \multirow[t]{2}{*}{ 3-й } & $\mathrm{S}_{\mathrm{t}}$ & 99 & 92 & 94 & 82 & 80 & 91 & 80 \\
\hline & $V$ & $2 \%$ & $8 \%$ & $8 \%$ & $18 \%$ & $20 \%$ & $10 \%$ & $20 \%$ \\
\hline \multirow[t]{2}{*}{ 5-й } & $\mathrm{S}_{\mathrm{t}}$ & 89 & 85 & 86 & 45 & 47 & 56 & 22 \\
\hline & $V$ & $12 \%$ & $15 \%$ & $16 \%$ & $55 \%$ & $53 \%$ & $45 \%$ & $78 \%$ \\
\hline \multirow[t]{2}{*}{ 7-й } & $\mathrm{S}_{\mathrm{t}}$ & 82 & 79 & 82 & 27 & 27 & 35 & 11 \\
\hline & $V$ & $19 \%$ & $21 \%$ & $20 \%$ & $73 \%$ & $73 \%$ & $65 \%$ & $89 \%$ \\
\hline \multirow[t]{2}{*}{ 9-й } & $S_{t}$ & 76 & 68 & 72 & 12 & 13 & 16 & - \\
\hline & V & $25 \%$ & $32 \%$ & $29 \%$ & $88 \%$ & $87 \%$ & $84 \%$ & $100 \%$ \\
\hline \multirow[t]{2}{*}{ 11-й } & $S_{t}$ & 64 & 42 & 45 & 4 & 5 & 9 & - \\
\hline & $V$ & $37 \%$ & $58 \%$ & $56 \%$ & $96 \%$ & $95 \%$ & $91 \%$ & - \\
\hline \multirow[t]{2}{*}{ 13-й } & $\mathrm{S}_{\mathrm{t}}$ & 56 & 30 & 33 & - & - & 1 & -- \\
\hline & $V$ & $45 \%$ & $70 \%$ & $68 \%$ & $100 \%$ & $100 \%$ & $99 \%$ & \\
\hline \multirow[t]{2}{*}{ 15-й } & $\mathrm{S}_{\mathrm{t}}$ & 45 & 25 & 29 & - & - & - & -- \\
\hline & $V$ & $55 \%$ & $75 \%$ & $72 \%$ & & & $100 \%$ & \\
\hline
\end{tabular}

Примітки: $S_{y}$ - початкова площа рани, мм;

$S_{t}$ - площа рани в день вимірювання, мм;

$V$ - швидкість загоєння ран - відсоток активності досліджуваних Л3, \%.

Результати кількісних морфологічних й імуногістохімічних досліджень свідчать про те, що розроблена мазь, у порівнянні 3 препаратами порівняння, сприяє переходу адекватної клітинно-тканинної запальної реакції до формування i дозрівання грануляційної тканини у фіброзну в терміни від 5 до 7 діб, що випереджує терміни загоєння ран у хворих групи порівняння в середньому в 1,7 рази.
Планіметричні дослідження показали достовірне зменшення розміру ран у хворих основної групи: на 5-у добу площа ран зменшувалась в середньому відповідно на $21,0 \%$, у групі порівняння - 14,8 \%, на 9-у добу рани у хворих основної групи загоїлись, у групі порівняння - 44,7 \%. Тривалість загоєння ран при застосуванні розробленої мазі склала $7,2 \pm 0,3$ доби, що в 1,5 рази активніше, ніж у хворих групи порівняння. 


\section{Висновки}

1. Отримані результати свідчать про високу ефективність розробленої ранозагоювальної мазі 3 метилурацилом, декаметоксином та ментолом під умовною назвою «МДМ-мазь» 3 протизапальною, антимікробною та анестезуючою дією для використання в гнійно-запальну фазу ранового процесу. Основними факторами при цьому $\epsilon$ : активний вплив на перебіг запального процесу в рані, а також істотне

\section{Література}

1. Визначення якісного складу сучасних ранозагоюючих засобів для потреб медичної служби Збройних Сил України на особливий період / В. О. Тарасенко, О. П. Шматенко, О. В. Підлісний, А. М. Соломенний, Л. Л. Давтян. Проблеми військової охорони здоров'я : зб. наук. пращь УВМА. 2019. Вип. 45. C. $134-145$

2. Тарасенко В. О., Кучмістова О. Ф., Соломенний А. М., Підлісний О. В. Структуризація особливостей та наслідків бойової травми у військовослужбовців. Військова медицина України. 2020. T. 19, № 4. С. 111-117.

3. Тарасенко В. О., Підлісний О. В., Козіко Н. О., Соломенний А. М. Обгрунтування технологічних параметрів ведення процесу виготовлення крему для лікування інфекційних та гнійно-запальних захворювань шкіри. Здоров'я суспільства. 2020. Том 8, № 5. С. 186-192.

4. Висвітлення окремих аспектів засобів для лікування ран i ранової інфекції: історикоеволюційний підхід / В. О. Тарасенко, Л. Л. Давтян, Д. С. Волох, О. Ф. Кучмістова, А. М. Соломенний, Н. О. Козіко. Фітотерапія. Часопис. 2020. № 2. С. 43-47.

5. Technological and Biopharmaceutical Aspects of Developingthe Basics of Soft Medicinal Local Action / V. Tarasenko, A. Pidlisnyy, A. Koval, A. Solomennyy, V. Vaschuk, L. Davtian, N. Goncharenko, I. Sakhanda, M. Naumova. Arch Pharma Pract. 2020. 11(1). P. 92-99.

6. Theoretical Basis of Creation of Soft Medicinal Products of Local Application / Viktoria Tarasenko, Dmytro Volokh, Andrii Solomennyi, Lena Davtian, Anna Drozdova, Oleksandr Shmatenko, Mariana Naumova, Ivanna Sakhanda. Journal of Global Pharma Technology. 2020. № 12 (06). P. 32-36.

7. The Study of Structural-Mechanical and Physicochemical Properties of the Drug Antimicrobial and Anesthetic Action / V. Tarasenko, A. Solomennyy, A. Pidlisnyy, A. Koval, V. Vaschuk, A. Shmatenko, L. Davtian, N. Takhtaulova, I. Sakhanda, N. Koziko, M. Shumeiko. Journal of Global Pharma Technology. 2020. № 12 (06). P. 32-36.

8. Технологічні аспекти створення м'яких лікарських засобів для лікування гнійних ран (огляд літератури) / О. П. Шматенко, О. В. Підлісний, Т. В. Приходько, А. М. Соломенний, Р. Л. Притула, Г. Б. Семенченко, Н. О. Тахтаулова. Український журнал військової медицини. 2020. Т. 1, № 1. С. 50-63. зниження виразності ендогенної інтоксикації при гнійно-запальних процесах м'яких тканин.

2. На даному етапі розвитку медичної науки і практики визначені оптимальні схеми застосування ранозагоювальних засобів у обраних клініко-економічних групах для місцевого лікування ран.

\section{Перспективи подальших досліджень} - розробка комплексних препаратів для певних фаз ранового процесу, що дозволяють одночасно впливати на декілька факторів патогенезу.

9. Шматенко О. П., Соломенний А. М., Підлісний 0. В., Тарасенко В. О. Визначення оптимальних моделей місцевого лікування ран у медичній службі Збройних Сил України : Science, society, education : topical issues and development prospects. Abstracts of the 2nd International scientific and practical conference. SPC «Sci-conf.com.ua». January 20-21, 2020. Kharkiv, Ukraine. P. 141-143. URL: http://sci-conf.com.ua/wp-

content/uploads/2020/01/science-societyeducation_topical-issues-and-developmentprospects_20-21.01.2020.pdf.

10.Підлісний О. В., Тарасенко В. О., Соломенний А. М. Технологічні аспекти створення МЛЗ для лікування гнійних ран. Здоров'я людини у сучасному світі : питання медичної науки та практики : матеріали міжнародної науково-практичної конференції (м. Одеса, 15-16 трав. 2020 р.). Одеса, 2019. C. 23-28.

11.Державна фармакопея України. Друге вид. Харків : дП «Український науковий фармакопейний центр якості лікарських засобів», 2015. Т. 1. С. 775-776.

12. Руденко В. В., Шматенко О. П., Притула Р. Л. Методика нормування м'яких лікарських засобів для військово-медичної служби при виникненні надзвичайних станів та в особливий період. Свідоцтво про реєстрацію авторського права на твір № 45283 від 22.08.2012 року.

13.Коскин В. С. Совершенствование системы профилактики раневой инфекции у раненых на этапах медицинской эвакуации : дис. ... к-та мед. наук : 14.01.17. Санкт-Петербург, 2016. 148 с.

14. Фармацевтические и биологические аспекты мазей : монография / под ред. И. М. Перцева. Харьков : Изд-во НФаУ : Золотые страницы, 2003. 288 с.

15.Оценка эффективности применения современных перевязочных материалов в комплексном лечении гнойных ран / С. Е. Каторкин и др. Амбулаторная хирургия. 2019 № 1-2. С. 146152. DOI: https://doi.org/10.21518/1995-1477-20191-2-146-152.

16.Поповичева М. Новые направления по заживлению ран. Україна. Здоров'я нації. 2020. № 3 (60). C. 120-124. DOI 10.24144/20776594.3.2020.209979. 
17.Кондратюк В. M. Антимікробна дія антисептичних препаратів на клінічні штами мікроорганізмів, що контамінують бойові поранення кінцівок. Проблеми військової охорони здоров'я : зб. наук. праць УВМА. 2017. Вип. 47. С. 277284.

18. Доклинические

исследования лекарственных средств : метод. рекомендации / под ред. А. В. Стефанова. Киев : Авицена, 2002. 568 с.

\section{References}

1. Tarasenko V. O., Shmatenko O. P., Pidlisnyi O. V., Solomennyi A. M., Davtian L. L. (2019). Vyznachennia yakisnoho skladu suchasnykh ranozahoiuiuchykh zasobiv dlia potreb medychnoi sluzhby Zbroinykh Syl Ukrainy na osoblyvyi period [Determining what corresponds to modern early means for the needs of the medical service of the Armed Forces of Ukraine for a special period]. Problemy viiskovoi okhorony zdorovia : zb. nauk. prats UVMA. 45, 134-145 [in Ukrainian].

2. Tarasenko V. O., Kuchmistova O. F., Solomennyi A. M., Pidlisnyi O. V. (2020). Strukturyzatsiia osoblyvostei ta naslidkiv boiovoi travmy $u$ viiskovosluzhbovtsiv [Structuring the features and consequences of combat injuries in servicemen]. Viiskova medytsyna Ukrainy, 19 (4), 111-117 [in Ukrainian].

3. Tarasenko V. O., Pidlisnyi O. V., Koziko N. O., Solomennyi A. M. (2020). Obgruntuvannia tekhnolohichnykh parametriv vedennia protsesu vyhotovlennia kremu dlia likuvannia infektsiinykh ta hniino-zapalnykh zakhvoriuvan shkiry [Substantiation of technological parameters of the process of making cream for the treatment of infectious and purulentinflammatory skin diseases]. Zdorovia suspilstva. 8 (5), 186-192 [in Ukrainian].

4. Tarasenko V. O., Davtian L. L., Volokh D. S., Kuchmistova O. F., Solomennyi A. M., Koziko N. O. (2020). Vysvitlennia okremykh aspektiv zasobiv dlia likuvannia ran i ranovoi infektsii: istoryko-evoliutsiinyi pidkhid [Coverage of certain aspects of means for the treatment of wounds and wound infection: a historicalevolutionary approach]. Fitoterapiia. Chasopys. 2, 43-47 [in Ukrainian].

5. Tarasenko V., Pidlisnyy A., Koval A., Solomennyy A., Vaschuk V., Davtian L., et al. (2020). Technological and Biopharmaceutical Aspects of Developingthe Basics of Soft Medicinal Local Action. Arch Pharma Pract. 11(1), 92-99.

6. Tarasenko Viktoria, Volokh Dmytro, Solomennyi Andrii, Davtian Lena, Drozdova Anna, Shmatenko Oleksandr, et al. (2020). Theoretical Basis of Creation of Soft Medicinal Products of Local Application. Journal of Global Pharma Technology. 12 (06), 32-36.

7. Tarasenko V., Solomennyy A., Pidlisnyy A., Koval A., Vaschuk V., Shmatenko A. et al. (2020). The Study of Structural-Mechanical and Physicochemical Properties of the Drug Antimicrobial and Anesthetic Action. Journal of Global Pharma Technology. 12 (06), 32-36.

8. Shmatenko O. P., Pidlisnyi O. V., Prykhodko T. V., Solomennyi A. M., Prytula R. L., Semenchenko H. B., Takhtaulova N. O. (2020). Tekhnolohichni aspekty stvorennia m'iakykh likarskykh zasobiv dlia likuvannia hniinykh ran (ohliad literatury) [Technological aspects of creating soft drugs for the treatment of purulent
19.Жолус Б.И., Омельчук В.В., Баранов А.П. Особенности проведения медицинских мероприятий в подразделениях миротворческих сил в Боснии и Герцеговине. Военно-медицинский журнал. 2008. №3. С. 60-65.

20. Минцер О.П., Угаров Б.Н., Власов В.В. Методы обработки медицинской информации : учебное пособие. Київ : Вища школа, 2001. 271 с.

wounds (literature review)]. Ukrainskyi zhurnal viiskovoi medytsyny. 2020. 1 (1), 50-63 [in Ukrainian].

9. Shmatenko O. P., Solomennyi A. M., Pidlisnyi 0. V., Tarasenko V. O. (2020). Vyznachennia optymalnykh modelei mistsevoho likuvannia ran u medychnii sluzhbi Zbroinykh Syl Ukrainy [Determination of optimal models of local wound healing in the medical service of the Armed Forces of Ukraine]. Science, society, education : topical issues and development prospects. Abstracts of the 2nd International scientific and practical conference. SPC «Sci-conf.com.ua». January 20-21. Kharkiv, Ukraine. 141-143. Retrieved from http://sci-conf.com.ua/wp-

content/uploads/2020/01/science-societyeducation_topical-issues-and-developmentprospects_20-21.01.2020.pdf [in Ukrainian].

10.Pidlisnyi O. V., Tarasenko V. O., Solomennyi A. M. (2019). Tekhnolohichni aspekty stvorennia MLZ dlia likuvannia hniinykh ran [Technological aspects of MLZ creation for treatment of purulent wounds]. Zdorovia liudyny u suchasnomu sviti : pytannia medychnoi nauky ta praktyky : materialy mizhnarodnoi naukovopraktychnoi konferentsii (Odesa, 15-16 trav. 2020 r.). Odesa. 23-28 [in Ukrainian].

11. Derzhavna farmakopeia Ukrainy. (2015). Druhe vyd. Kharkiv : DP «Ukrainskyi naukovyi farmakopeinyi tsentr yakosti likarskykh zasobiv» [in Ukrainian].

12. Rudenko V. V., Shmatenko O. P., Prytula R. L. (2012). Metodyka normuvannia miakykh likarskykh zasobiv dlia viiskovo-medychnoi sluzhby pry vynyknenni nadzvychainykh staniv ta $\mathrm{v}$ osoblyvyi period [Methods of rationing of soft medicines for military medical service in case of emergencies and in a special period]. Svidotstvo pro reiestratsiiu avtorskoho prava na tvir № 45283 [in Ukrainian].

13. Koskyn V. S. (2016). Sovershenstvovanye systemy profylaktyky ranevoi ynfektsyy u ranenыkh na etapakh medytsynskoi evakuatsyy [Improvement of the system of prevention of wound infection in the wounded at the stages of medical evacuation]. Extended abstract of candidate's thesis. SanktPeterburh [in Russian].

14.Pertseva Y. M. (2003). Farmatsevtycheskye y byolohycheskye aspekty mazei : monohrafyia [Pharmaceutical and biological aspects of ointments: monograph]. Kharkov : Yzd-vo NFaU : Zolotыe stranytsy. [in Russian].

15. Katorkyn S. E. (2019). Otsenka effektyvnosty prymenenyia sovremennykh pereviazochnykh materyalov $\mathrm{v}$ kompleksnom lechenyy hnoinykh ran [Evaluation of the effectiveness of the use of modern dressings in the complex treatment of purulent wounds]. Ambulatornaia khyrurhyia. 1-2, 146-152. DOI: 
https://doi.org/10.21518/1995-1477-2019-1-2-146152 [in Russian].

16. Popovycheva M. (2020). Novye napravlenyia po zazhyvlenyiu ran [New directions for wound healing] Ukraina. Zdorovia natsii. 3 (60), 120-124. DOI 10.24144/2077-6594.3.2020.209979 [in Russian].

17. Kondratiuk V. M. (2017). Antymikrobna diia antyseptychnykh preparativ na klinichni shtamy mikroorhanizmiv, shcho kontaminuiut boiovi poranennia kintsivok [Antimicrobial action of antiseptic drugs on clinical strains of microorganisms that contaminate combat wounds of the extremities]. Problemy viiskovoi okhorony zdorovia : zb. nauk. prats UVMA. 47, 277-284 [in Ukrainian].

18.Stefanova A. V. (2002). Doklynycheskye yssledovanyia lekarstvennыkh sredstv : metod. rekomendatsyy [Preclinical studies of drugs: method. recommendations]. Kyev : Avytsena.[in Russian].

19.Zholus B.Y., Omelchuk V.V., Baranov A.P. (2008). Osobennosty provedenyia medytsynskykh meropryiatyi $\mathrm{v}$ podrazdelenyiakh myrotvorcheskykh syl v Bosnyy y Hertsehovyne [Features of medical activities in peacekeeping units in Bosnia and Herzegovina]. Voenno-medytsynskyi zhurnal. 3, 60-65 [in Russian].

20. Myntser O.P., Uharov B.N., Vlasov V.V. (2001). Metody obrabotky medytsynskoi ynformatsyy: uchebnoe posobye [Medical Information Processing Techniques: A Study Guide]. Kyiv: Vyshcha shkola.[in Russian].

\title{
ОПРЕДЕЛЕНИЯ КАЧЕСТВЕННОГО СОСТАВА СОВРЕМЕННЫХ РАНОЗАЖИВЛЯЮЩИХ СРЕДСТВ ДЛЯ НУЖД МЕДИЦИНСКОЙ СЛУЖБЫ ВООРУЖЕННЫХ СИЛ УКРАИНЫ В МИРНОЕ ВРЕМЯ И В ОСОБЫЙ ПЕРИОД
}

\author{
А.Н. Соломенный \\ Украинская военно-медицинская академия, г. Киев, Украина
}

Вступление. Одной из самых больших проблем, которая встает перед военными врачами в мирное время, а также появилась при ведении боевых действий в условиях проведения операции Объединенных сил и антитеррористической операции и, вероятно, потребует решения на этапе последующего лечения и реабилитации раненых военнослужащих, является оптимизация схем местного лечения ран и профилактики раневой инфекции, которое должно осуществляться в строгом соответствии с фазами раневого процесса. Ранозаживляющие препараты, которые находятся на оснащении подразделений военно-медицинской службы имеют ряд недостатков, среди которых основными являются недостаточная регенеративная активность, высокий риск микробной контаминации раны и необходимость частой замены на раневом поле. Поэтому чрезвычайно актуальными становятся исследования, направленные на разработку технологических схем получения современных мягких лекарственных средств комплексного действия отечественного производства для местного лечения ран, а также введение в нормы поставки таких ранозаживляющих лекарственных средств, в виде мази и раневых гидрогелевых повязок, которые обладают антибактериальными, анестезирующими, противовоспалительными и антимикробными свойствами, а также не требуют частой замены в процессе медикаментозного обеспечения военнослужащих.

Цель исследования - исследовать качественный состав современных ранозаживляющих лекарственных средств для нужд медицинской службы Вооруженных сил Украины в мирное время и в особый период.

Материалы и методы. Материалами служили медищинские карты стационарных больных и листы назначений раненых и больных с повреждениями кожных покровов. В работе применены документальный, обще гистологический, гистохимический, морфометрический и статистический методы исследования.

Результаты исследования. $C$ целью определения качественного состава норм снабжения ранозаживляющих средств местного действия нами были проанализированы медицинские карты стационарных больных и листы назначений раненых и больных с повреждением кожных покровов. Вмодель исследование были включены условно загрязненные раны диаметром 10 см и глубиной раны от 5 до 10 мм. Проведенный анализ результатов медикаментозного обеспечения больных с гнойно-воспалительными процессами мягких тканей, находившихся на лечении по поводу гнойных ран и интраоперационной профилактики раневой инфекции в 65 больных, составивших основную группу. Анализ эффективности применения разработанной МДМ-мази при лечении гнойных ран проводился по сравнению с результатами лечения 110 пациентов с острыми гнойными первичными ранами (72,5\%), составивших группу сравнения, которая была разделена на 5 подгрупп. Среди них абсцессы мягких тканей, флегмоны клеточных пространств туловища и конечностей наблюдались в 54 (35,2\%) больных, различные формы панариция 25 (16,2\%) и парапроктита - 12 (8,9\%) пациентов. Поровну распределились больные с острым гнойным бурситом, карбункулом (12,1\% наблюдений). Результаты микробиологических исследований раневых выделений были положительными у всех групп пациентов. При этом в 60 больных (44,7\%) флора представлена монокультурой, у других пациентов с раны выделены ассоциации микроорганизмов. $B$ микробном пейзаже наблюдалась преимущество грамположительной флоры. Большинство идентифицированных микроорганизмов составили стафилококки, среди которых чаще всего выделялся $S$. aurerus (55,6\% пациентов), при четкой тенденции к повышению роли S. epidermidis (30,8\% больных), a 
также S. faecalis (15,5\% больных). В ряде грамотрицательных бактерий преобладали E. соli (76,4\% больных), значительно реже наблюдались бактерии рода Proteus (11,7\% больных), Pseudomonas aerugenosa (3,7\% больных) и клебсиелла - 1,9\%. Энтерококки выделены - в 5,6\%, B. subtilis - в 2,8\% больных. Среди больных, которые наблюдались, у 8 человек были выделены следующие микроорганизмы: палочки группы Bacteroides - 5 пациентов, из них в 2 бактероиды группы B. fragilis, а в трех - B. melaninogenicus. B двух человек обнаружены грамположительные кокки группы Peptostreptococcus sp., и у одного пациента была выделена факультативно анаэробная микрофлора. При анализе течения раневого процесса в ходе лечения больных разработанной мазью под условным названием «МДМ-мазь» обращает на себя внимание быстрое уменьшение воспалительно-экссудативных изменений в ране, в основном до 3 суток лечения. Оценивая эффективность антимикробного действия разработанной мази необходимо подчеркнуть, что она подавляет внутритканевую микрофлору, не достигается при лечении другими мазями, что обусловлено как гидрофильной основой, так и активными фармацевтическими ингредиентами, так как именно внутритканевая микрофлора определяет тяжесть и направленность раневого процесса.

Выводы. Полученные результаты свидетельствуют о высокой эффективности разработанной ранозаживляющей мази с метилурацилом, декаметоксином и ментолом под условным названием «МдМмазь» с противовоспалительным, антимикробным и анестезирующим действием для использования в гнойно-воспалительный фазу раневого процесса. Основными факторами при этом являются: активное воздействие на ход воспалительного процесса в ране, а также существенное снижение выраженности эндогенной интоксикации при гнойно-воспалительных процессах мягких тканей. На данном этапе развития медицинской науки и практики определены оптимальные схемы применения ранозаживляющих средств в избранных клинико-экономических группах для местного лечения ран.

Ключевые слова: мазь, раневой процесс, воспаление, ранения.

\title{
DETERMINATION OF QUALITATIVE COMPOSITION OF MODERN WOUND-HEALING DRUGS FOR THE NEEDS OF THE MEDICAL SERVICE OF THE ARMED FORCES OF THE UKRAINE FOR THE PEACE TIME AND THE SPECIAL PERIOD
}

\author{
A.M. Solomenniy \\ Ukrainian Military Medical Academy, Kyiv, Ukraine
}

Introduction. One of the biggest problems that confronts military doctors in peacetime, and also appeared during the conduct of hostilities under the conditions of the Joint Forces Operation and the Anti-Terrorist Operation (JF (ATO)) and will probably require a solution at the stage of subsequent treatment and rehabilitation of the wounded military personnel, is the optimization of schemes for local treatment of wounds and prevention of wound infection, which should be carried out in strict accordance with the phases of the wound process. Wound-healing drugs that are on the equipment of military medical service units have a number of disadvantages, among which the main ones are insufficient regenerative activity, a high risk of microbial contamination of the wound and the need for frequent replacement in the wound field. Therefore, studies aimed at the development of technological schemes for the production of modern soft drugs (MSD) with a complex effect of domestic production for local treatment of wounds, as well as the introduction of such wound healing drugs in the supply standards, in the form of ointments and wound hydrogel dressings, which have antibacterial, anesthetic, anti-inflammatory and antimicrobial properties, and also do not require frequent replacement in the process of providing medical supplies to servicemen.

The purpose - to study the qualitative composition of modern wound-healing medicines for the needs of the medical service of the Armed Forces of Ukraine in peacetime and for a special period.

Materials and methods. The materials were medical records of inpatients and prescription sheets of wounded and patients with skin injuries. The paper used documentary, general histological, histochemical, morphometric and statistical research methods.

Results. In order to determine the quality of the supply of wound healing agents of local action, we analyzed the medical records of inpatients and letters of appointment of the wounded and patients with damaged skin. The study model included conditionally contaminated wounds with a diameter of $10 \mathrm{~cm}$ and a wound depth of 5 to $10 \mathrm{~mm}$. An analysis of the results of drug supply of patients with purulent-inflammatory processes of soft tissues who were treated for purulent wounds and intraoperative prevention of wound infection in 65 patients who made up the main group. The analysis of the effectiveness of the developed MDM ointment in the treatment of purulent wounds was performed in comparison with the results of treatment of 110 patients with acute purulent primary wounds (72.5\%), which was a comparison group, which was divided into 5 subgroups. Among them, soft tissue abscesses, phlegmons of the cell spaces of the trunk and extremities were observed in 54 (35.2\%) patients, various forms of panaritium - 25 (16.2\%) and paraproctitis - 12 (8.9\%) patients. Patients with acute purulent bursitis and carbuncle were equally distributed (12.1\% of cases). The results of microbiological studies of wound secretions were positive in all groups of patients. At the same time in 60 patients (44.7\%) the flora is represented by monoculture, in other patients associations of microorganisms are isolated from the wound. The predominance of gram-positive flora was observed in the microbial landscape. The majority of identified microorganisms were staphylococci, among which the most common was $S$. aurerus (55.6\% of patients), with a clear tendency to increase the role of S. epidermidis (30.8\% of patients) and $S$. faecalis (15.5\% of patients). E. coli (76.4\% of patients) predominated in a number of gram-negative bacteria, bacteria of the genus Proteus (11.7\% of patients), Pseudomonas aerugenosa (3.7\% of patients) and 
Klebsiella - 1.9\% - were observed much less often. Enterococci were isolated in 5.6\%, B. subtilis in 2.8\% of patients. Among the observed patients, the following microorganisms were isolated in 8 people: Bacteroides bacilli - 5 patients, including 2 bacteroids of the B. fragilis group, and three - B. melaninogenicus. Gram-positive cocci of Peptostreptococcus sp. Group were found in two people, and one patient had facultative anaerobic microflora. Analysis of the course of the wound process during the treatment of patients with the developed ointment under the conditional name "MDM-ointment" shown to the rapid reduction of inflammatory and exudative changes in the wound, mainly up to 3 days of treatment. Assessing the effectiveness of the antimicrobial action of the developed ointment, it should be emphasized that it suppresses the intratissue microflora, which is not achieved in the treatment of other ointments, due to both hydrophilic basis and active pharmaceutical ingredients.

Conclusions. The obtained results testify to the high efficiency of the developed wound-healing ointment with methyluracil, decamethoxine and menthol under the conditional name "MDM-ointment" with antiinflammatory, antimicrobial and anesthetic action for use in the purulent-inflammatory phase of the wound process. The main factors are: active influence on the course of the inflammatory process in the wound, as well as a significant reduction in the severity of endogenous intoxication in purulent-inflammatory processes of soft tissues. At this stage of development of medical science and practice the optimal schemes of application of wound-healing means in the chosen clinical and economic groups for local treatment of wounds are defined.

Keywords: ointment, wound process, inflammation, injury.

\section{Відомості про автора:}

Соломенний А.М., підполковник медичної служби, кандидат фармацевтичних наук, доцент, доцент кафедри військової фармації Української військово-медичної академії, м. Київ, Україна. ORCID ID: https://orcid.org/0000-0002-9562-8321, e-mail: solomennyy@ukr.net.

\section{Сведения об авторе:}

Соломенный A.M., подполковник медицинской службы, кандидат фармацевтических наук, доцент, доцент кафедры военной фармации Украинской военно-медицинской академии., г. Киев, Украина. ORCID ID: https://orcid.org/0000-0002-9562-8321, e-mail: solomennyy@ukr.net.

Information about the author:

Solomenny A.M., LTC MS, PhD, Assoc. Prof., Associate Professor of the Department of Military Pharmacy of the Ukrainian Military Medical Academy, Kyiv, Ukraine. ORCID ID: https://orcid.org/0000-0002-9562-8321, e-mail: solomennyy@ukr.net.

Адреса для листування: вул. Московська, 45/1, буд. 33, м. Київ, 01015. 